\title{
PEMBUATAN DAN PENGUJIAN SOLAR CHARGER BATTERY UNTUK SMARTPHONES
}

\author{
Sri Utami, Agoeng H Rahardjo, Teguh A Pamungkas \\ Jurusan Teknik Konversi Energi \\ Politeknik Negeri Bandung \\ utamiwu@yahoo.com
}

\begin{abstract}
Abstrak
Berbagai fungsi yang dapat didukung oleh perangkat mobile membuatnya lebih penting dan lebih sering digunakan . Hal ini membuat keberadaan smartphone ada di mana-mana . Kebutuhan pengisian baterai terus meningkat seiring dengan pemakaian listriknya. Inovasi baru yang menjadi perhatian adalah seperti pada pengisi baterai surya yang menggunakan energi dari radiasi matahari . Output baterai perlu diperhatikan untuk memastikan dapat mengisi ulang baterai smartphone. Solar charger battery akan berguna karena kita tidak perlu listrik dari pemasok. Solar charger battery yang dikembangkan dalam penelitian ini memiliki tegangan output 5 volt DC . Pengguna dapat memanfaatkannya untuk mengisi ulang baterai smartphone. Hasil penelitian menunjukkan, pengisi baterai surya mengisi penuh setelah 100-120 menit dengan rata-rata radiasi matahari $393 \mathrm{~W} / \mathrm{m}^{2}$ dan rata-rata efisiensi sel surya solar charger battery $19,84 \%$. Solar charger battery ini dapat digunakan untuk 2 sampai 3 proses pengisian tergantung pada spesifikasi smartphonenya.
\end{abstract}

Kata kunci : surya pengisi baterai, smartphone, efisiensi

\begin{abstract}
Various functions that can be supported by the mobile devices makes it even more important and often used. This makes smartphones ubiquitous. Battery charging is increases and needs electricity. The new innovation is concerned like solar battery charger which use electricity from sun radiation. The battery output is needed attention to make sure it can recharge battery of smartphone. Solar battery charger will useful because we do not need electricity from supplier. This solar battery charger has output voltage 5 volt DC. User can harness it to recharge battery of smartphone. According to the experiment results, this solar battery charger was fully charge after 100-120 minutes with average of sun radiation $393 \mathrm{~W} / \mathrm{m}^{2}$ and average of solar cell efficiency was $19,84 \%$. This solar battery charger is able to be used 2 until 3 charging process depend on specification of smartphone.
\end{abstract}

Key words : solar charger battery, smartphone, efficiency

\section{Pendahuluan}

Energi merupakan salah satu bagian penting dari pertumbuhan ekonomi suatu negara [ 1 ] . Energi dari bahan bakar konvensional seperti minyak bumi , gas alam , dan batu bara masih digunakan hingga $80 \%$ [ 2 ]. Fakta bahwa permintaan energi dunia saat ini dapat habis dengan cepat, tidak dapata dipungkiri . Selain itu, efek rumah kaca dan polusi adalah masalah yang berbeda bagi planet kita .

Salah satu perangkatyang membutuhkan energi berkesinambungan adalah smartphone. Popularitas dan berbagai ponsel yang meningkat tajam, dengan penjualan di seluruh dunia mendekati 301.300 .000 unit, naik $25,3 \%$ dari 240.500.000 unit dikapalkan pada tahun 2013 
[4]. Hal ini memungkinkan pengguna untuk dapat memperolehnya di mana saja dan dapat terhubung satu sama lain. Selain itu, pengguna dimudahkan dengan akses internet, musik, pemutaran audio dan video dan rekaman, navigasi dan kemampuan komunikasi [ 3 ] . Berbagai fungsi yang membuat smartphone memerlukan lebih banyak energi untuk mendukung pengoperasiannya .

Energi surya telah digunakan di beberapa bagian dunia . Hal ini dapat mengurangi ketergantungan manusia pada ketersediaan bahan bakar fosil . Indonesia menerima sinar matahari sepanjang waktu . Ini adalah keuntungan besar karena negara ini terletak di daerah tropis. Salah satu manfaat dari energi surya dapat dimanfaatkan dalam sistem kelistrikan . Matahari adalah sumber utama yang dibutuhkan oleh sel surya . Menyerap energi radiasi matahari dan mengubahnya menjadi energi listrik . Pada sistem listrik, tenaga surya akan digunakan untuk mengisi ulang baterai daya smartphone yang dikenal sebagai pengisi baterai solar. Pengisi baterai, hari ini , masih menggunakan listrik dari pemasok untuk melakukan pengisian daya. Kurangnya charger baterai menggunakan tenaga surya sebagai sumber listrik merupakan topik pada penelitian ini .

\section{Metode}

Surya sel, juga dikenal sebagai fotovoltaik , adalah persimpangan P-N dari silikon kristal tunggal . Bahan ini dapat mengumpulkan dan mengkonversi radisai surya menjadi energi listrik dengan menggunakan efek foto - listrik semikonduktor . Energi listrik dari sel surya di DC . Energi ini bisa langsung digunakan, atau bisa juga menggunakan baterai sebagai suatu sistem penyimpanan, sehingga dapat digunakan pada saat itu diperlukan .

\subsection{Karakteristik Sel Surya}

Dua karakteristik penting dari sel surya terbuka sirkuit tegangan ( Voc ), arus hubung singkat (ISC) . Karakteristik lain yang perlu diperhatikan adalah efek dari perubahan intensitas cahaya, perubahan efek suhu dan tegangan karakteristik arus ( V - I karakteristik ) pada sel surya [ 5$]$.

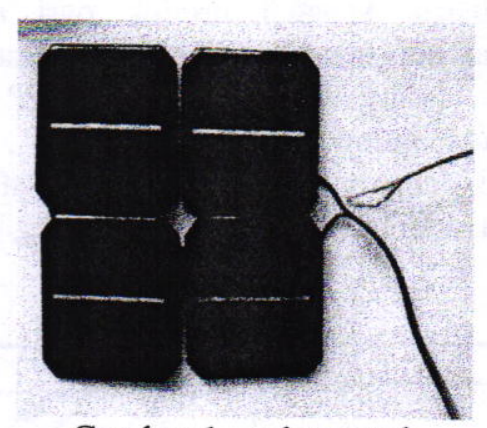

Gambar 1. solar panel

\subsection{1 . Tegangan open circuit ( Voc )}

Tegangan sirkuit terbuka ( Voc ) : tegangan antara terminal ketika tidak ada arus yang ditarik [ 6 ]. Untuk mencapai sirkuit terbuka ( Voc ) adalah dengan menghubungkan kutub positif dan kutub negatif dari modul surya dengan voltmeter.

\subsection{2 . Arus Short Circuit ( Isc )}

Hubungan pendek arus ( ISC ) : arus ketika terminal yang terhubung satu sama lain [6]

\subsection{3 - Karakteristik sel surya untuk pencahayaan yang berbeda}

Gambar 2 menjelaskan bahwa arus-tegangan dari solar cell sangat tergantung pada jumlah cahaya yang jatuh di atasnya .

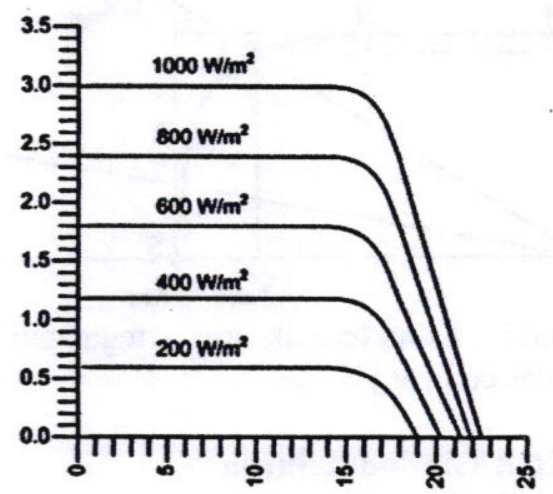

Gambar.2 . Kurva arus-tegangan dengan berbagai pencahayaan [ 7]

2.1.4 . Karakteristik sel surya untuk suhu yang berbeda 
Daya listrik sebagai produk dari arus dan tegangan sel memiliki daya maksimum yang berbeda , yang dikenal sebagai MPP ( power point maksimum ). Pada Gambar . 3. MPP ditandai dengan lingkaran. Untuk suhu yang berbeda akan menghasilkan MPP yang berbeda .

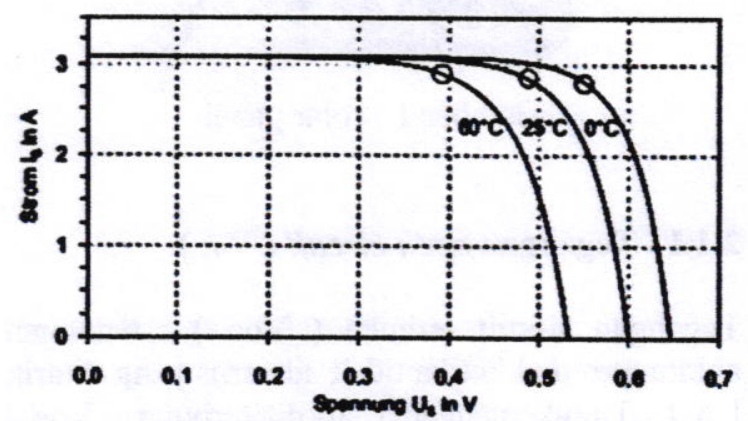

Gambar.3 . Karakteristik dari sel surya standar untuk suhu yang berbeda [ 8 ]

\subsection{5 . Karakteristik arus-tegangan untuk sel surya}

Gambar.4 mewakili ketika sel yang terhubung ke beban. Garis linier menunjukkan nilai daya yang tergantung pada perlawanan. Sel akan beroperasi di daerah $\mathrm{MN}$ jika nilai $\mathrm{R}$ kecil . Ini dikenal sebagai sirkuit pendek . Jika beban $R$ besar, sel akan beroperasi di PS kurva, dan ini dikenal sebagai rangkaian terbuka tegangan [9]

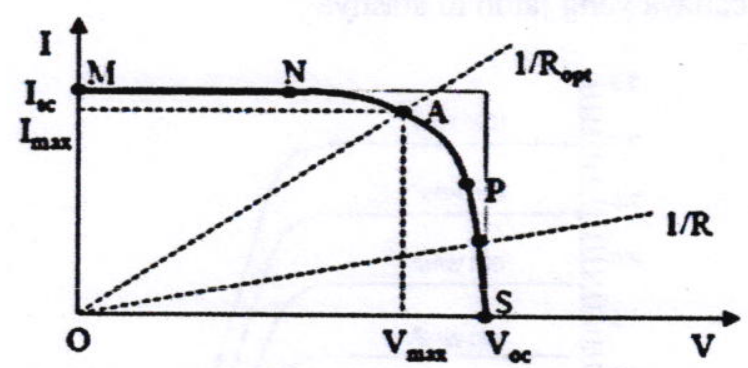

Gambar.4 . Karakteristik arus - tegangan untuk satu solar cell [ 9 ]

\section{2 . Koneksi Modul Surya}

\subsection{1 . Sel surya seri}

Jika pengguna perlu meningkatkan tegangan sel , dapat disusun secara seri . Arus yangdihasilkan saat ini akan tetap sama (Gambar 5).
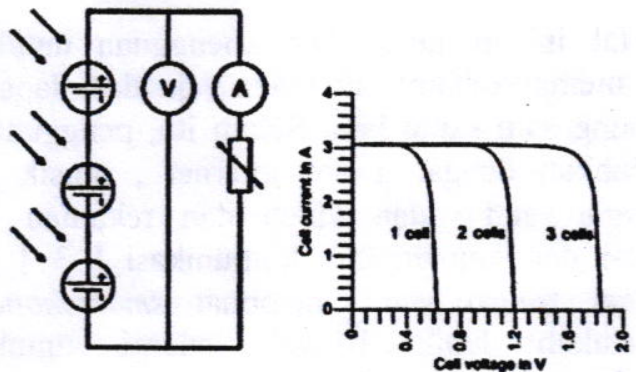

Gambar.5 . ( a) Sel surya dalam seri ( b ) kurva Saat tegangan sel surya dalam seri [ 7 ]

\subsubsection{Sel surya paralel}

Dalam connnection paralel, arus akan berubah, tapi tegangan akan tetap sama, Gambar.6 .

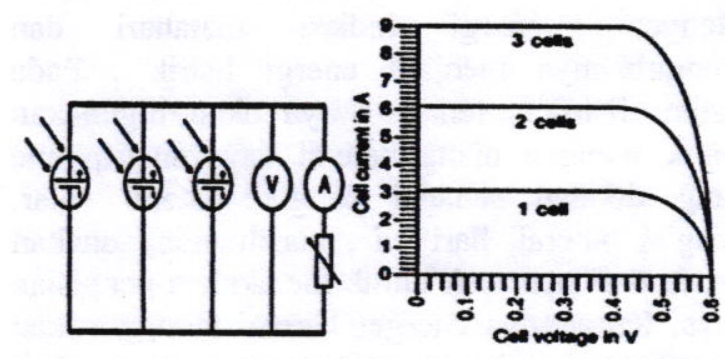

Gambar.6 . ( a) Sel surya secara paralel ( b ) kurva Saat tegangan sel surya secara paralel [ 7]

\section{3 . Regulator Tegangan}

Regulator tegangan adalah DC ke DC inverter . Rangkaian ini menggunakan sistem osilator tunggal dibangun oleh transistor dan sebuah kumparan . Output dari gulungan primer dihubungkan ke dioda . Hal ini digunakan untuk mengisi daya baterai . Fungsi utama dari kumparan ini adalah untuk menaikkan tegangan dari sel, yang selalu berubah tergantung radiasi matahari . Dengan cara itu output dari regulator dapat menempati standar tertentu . 


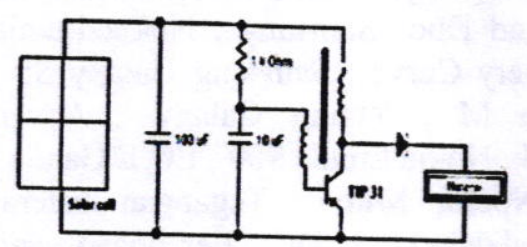

Gambar.7 . Sirkuit regulator tegangan

\subsection{Rangkaian Penyimpanan}

Rangkaian penyimpanan ini bertindak sebagai pelindung juga rangkaian multivibrator. Tegangan output dari regulator akan digunakan untuk mengisi baterai nikel metal hydride . Penelitian ini menggunakan 6 baterai seperti yang ditunjukkan pada Gambar.8 . Spesifikasi masing-masing baterai 1,2 volt DC $1150 \mathrm{mAh}$.

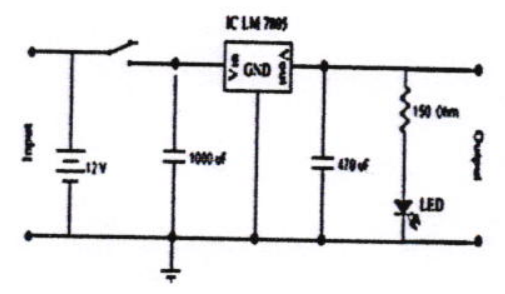

(a)

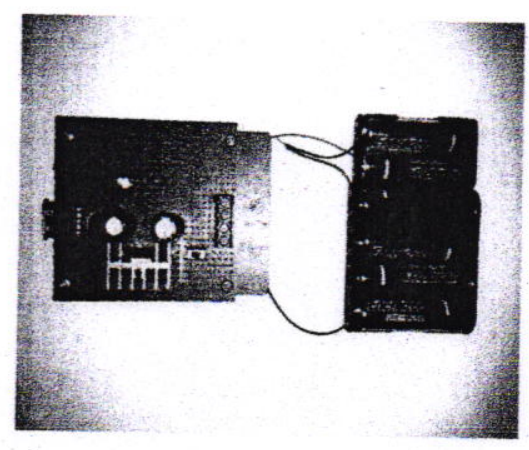

(b)

Gambar.8 . ( a) rangkaian penyimpanan ( b ) rangkaian penyimpanan yang sudah terealisasi

\subsection{Efisiensi sel surya}

Untuk menentukan efisiensi panel surya , perhitungan daya input dan daya output perlu dilakukan .

$\eta=$ ( Output Power ) / ( Input Power ) x $100 \%$ ( 1 )

\section{Hasil}

Variasi intensitas cahaya pada sel surya mengubah semua parameter pada sel surya . Arus dan tegangan sel berbanding lurus dengan intensitas cahaya.

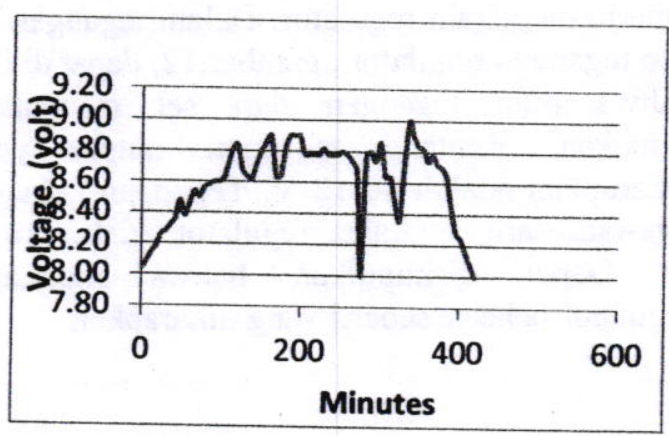

Gambar.9 . Variasi tegangan output, Selasa (0624-2014) 08:00-15:00 WIB

Output sel selalu berubah sesuai nilai radiasi seperti yang ditunjukkan pada Gambar.9. Ketika nilai radiasi mengalami kenaikan, tegangan akan naik juga, dan begitupun sebaliknya jika nilai radiasi turun . Namun , tegangan output masih tetap di kisaran $8-9 \mathrm{~V}$.

Dibandingkan dengan tegangan sel, yang memiliki karakteristik yang sama dengan tegangan.Hal ini ditampilkan pada gambar 10 . Nilai arus akan berubah sesuai dengan nilai radiasi . 


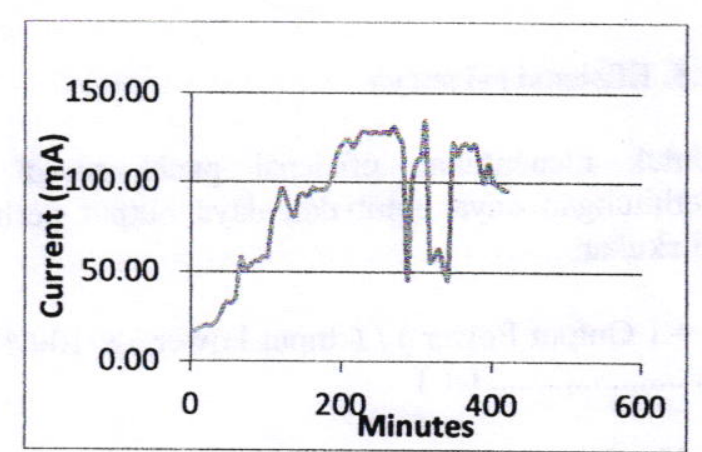

Gambar.10 . Variasi arus keluaran sel pada Selasa (06-24-2014) 08:00-15:00 WIB

\section{Regulator Tegangan}

Pengujian ini dimaksudkan untuk mengetahui kinerja rangakain regulator. Dalam tegangan sel dan tegangan regulator, gambar.12, dapat dilihat bahwa nilai tegangan dari sel mengalami kenaikan. Rentang tegangan output yang diharapkan adalah 10-12 V. Tegangan keluaran rata-rata dari rangkaian regulator adalah 10,94 V. Dapat disimpulkan bahwa rangkaian regulator bekerja seperti yang diharapkan .

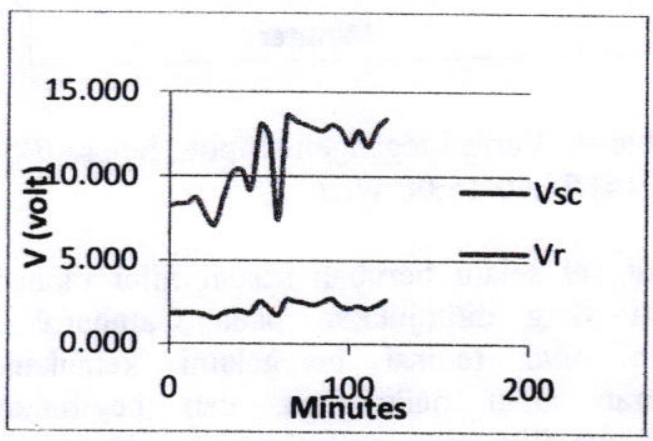

Gambar.11 . Tegangan regulator

\section{Efisiensi sel surya}

Perhitungan efisiensi dilakukan untuk mengetahui efisiensi panel surya yang digunakan . Menggunakan panel surya $0,01 \mathrm{~m}$ dan radiasi matahari rata-rata nilai $393 \mathrm{~W} / \mathrm{m} \wedge$ 2 diperoleh efisiensi rata-rata $19.84 \%$.

\section{Pengisian Baterai Penyimpanan}

Pengisian baterai pengujian dimaksudkan untuk menentukan waktu yang dibutuhkan oleh pengisi baterai surya untuk melakukan pengisian baterai smartphone sampai $100 \%$. Beberapa merek smartphone yang digunakan dalam penelitian ini , yang : Grand Duos Samsung, Nokia Lumia 502 , Blackbery Curve, Samsung Galaxy S5 , Sony Xperia M , Young Galaxy , Advan Vandroid S5J , Nokia Lumia 900 , LG E Ganda, dan Sony Xperia Miro . Tegangan baterai smartphone adalah 3,7 V DC . Percobaan yang dilakukan menunjukkan rentang waktu pengisian untuk merek tersebut adalah antara $100-120$ menit .

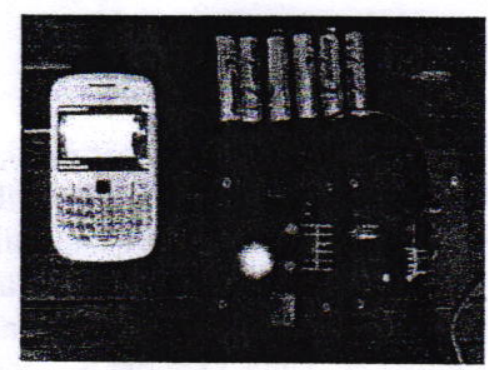

Gambar 13. Proses Battery-Charging 


\section{References}

[1] Oni, Joe Oladosu., Bolaji, Bukola Olalekan., "Development of a universal DC power supply using solar photovoltaic, utility and battery power sources"

[2] Tobnaghi ,Davud Mostafa ., Sojoudi, Mosaddegh., Madatov,Rahim., " Influence of Illumination Intensity on Electrical Parameters of Solar Cells"

[3] Ferreira, Denzil., Dey, Anind K., Kostakos, Vassilis., "Understanding Human-smartphone Concerns:A Study of Battery Life"

[4] Worldwide Quarterly Mobile Phone Tracker

[5] Satwiko S., "Uji Karakteristik Sel Surya pada Sistem 24 Volt DC sebagai Catudaya padasistem Pembangkit Tenaga Hybrid

[6]http://org.ntnu.no/solarcells

[7] Harper, Gavin D.J., "Solar Energy Projects for The Evil Genius"

[8] Wesselak, Viktor., Voswinckel, Sebastian., "Photovoltaik Wie Sonne zu Strom wird"

[9] Hansen, Anca D., Sorensen, Poul., Hansen, Lars H.,Bindner, Hendrik.,"Model for A StandAlone PV System" 